\title{
IMIGRAÇÃO, A MORTE DOS NÃO-HUMANOS E A IDOLATRIA
}

\author{
Immigration, the death of non-humans and the idolatry
}

\author{
Jung Mo Sung*
}

Resumo. A partir de dois casos de criminalização de voluntários que ajudaram imigrantes irregulares em situações de perigo de morte, o artigo analisa o processo de inversão da consciência moral, que consiste em interpretar uma ação solidária como um crime de traição e atentado contra a segurança nacional. Para isso, a partir da noção de oferta de sacrifícios de vidas humanas aos deuses modernos, inicialmente proposta por Weber, estudaremos como os imigrantes em situação irregular são vistos como inimigos-criminosos "não-humanos", que não merecem ajuda, e propomos o conceito de idolatria como chave de leitura em busca de caminhos de superação da insensibilidade social e das "guerras dos deuses".

Palavras-chave: imigração; neoliberalismo; sacrifício; deuses modernos; idolatria do mercado.

Abstract. Based on two cases of criminalization of volunteers who helped illegal immigrants in life-threatening situations, the article analyzes the process of reversal of moral conscience, which consists in interpreting solidarity action as a crime of treason and an attack on national security. To this end, from the notion of offering human life sacrifices to the modern gods, originally proposed by Weber, we will study how undocumented migrants are viewed as unhelpful "non-human" enemy criminals and proposes the concept of idolatry as a key reading in search of ways to overcome social insensitivity and the "wars of the gods".

Keyword: immigration; neoliberalism; sacrifice; modern gods; idolatry of Market.

Programa de Pós-Graduação em Ciências da Religião da Universidade Metodista de São Paulo. São Paulo - SP, Brasil. E-mail: jungmosung@gmail.com. Orcid: 0000-0001-7089-1185. 


\section{Dois casos, uma pergunta}

Há dois eventos judiciais relacionados à imigração irregular que chamaram atenção dos meios de comunicação nos últimos meses. O primeiro é o caso de um voluntário americano, Scott Warren, membro da organização No More Deaths/No Más Muertes, um dos muitos voluntários que percorrem o Deserto de Sonora, entre os Estados Unidos e México, para deixar água, comida e suprimentos básicos nas trilhas usadas pelos imigrantes, e que, por causa dessa atividade voluntária, pode pegar até 20 anos de prisão.

O segundo caso é o da capitã Carola Rackete, alemã, do navio Sea Watch 3, que trabalha no resgate de imigrantes no Mar Mediterrâneo. Trazendo a bordo 41 imigrantes resgatados na costa da Líbia, atracou no porto de Lampedusa sem a autorização das autoridades. Ela afirmou: "Basta. Depois de 16 dias entramos no porto". Logo depois, soldados embarcaram no navio e detiveram a capitã, que foi acusada de resistência e violência contra um navio de guerra, um crime que prevê uma sentença entre três e dez anos de prisão. Diante da situação, o então ministro do Interior da Itália, Matteo Salvini, pediu pena exemplar à capitã, quem ele chamou de "criminosa", "pirata" e perigosa para a segurança nacional. Ao contrário do ministro, a juíza Alessandra Vella alegou que a ativista "não violou nenhuma lei, mas apenas cumpriu seu dever de proteção da vida humana" e a libertou (O Globo, 2019).

Esses não são apenas dois casos excepcionais. Há numerosos episódios análogos, sobretudo na França (Penchaszadeh, Sferco, 2019), o que mostra que há algo novo no cenário: está em jogo o processo de criminalização de ações antes consideradas como "dever de proteção da vida humana" ou ações de solidariedade humana. Acredito que esses casos não ficarão na história como uma anedota jurídica, mas como uma "ponta de iceberg" que revela algo de mais profundo e grave.

A imigração, regular ou irregular, na segunda metade do século XX era considerada principalmente uma questão social e humanitária. No entanto, no início dos anos 2000, começou nos Estados Unidos um processo de criminalização dos imigrantes com a política pública de "crimigração" (Guia, Pedroso, 2015), que faz convergir a lei criminal com a lei de imigração, objetivando punir e expulsar os imigrantes. A passagem de uma concepção social e humanitária de política pública frente à imigração para uma de criminalização poderia ser entendida como uma forma de desincentivar a chegada de mais imigrantes, sem implicar necessariamente uma mudança cultural radical na sociedade que os recebe. Isto é, seria uma tentativa meramente "técnica" para resolver ou diminuir o "problema". Eu não quero discutir se isto é humano ou justo, mas poderíamos admitir que faz parte de um paradigma jurídico aceitável para a civilização moderna. 
No entanto, nos casos destacados, há uma ruptura cultural-civilizatória: as acusações não são contra imigrantes irregulares, mas sim contra cidadãos "regulares", por suas ações solidárias em favor de imigrantes em situações de perigos de morte. É como se esses acusados estivessem traindo o país agindo em favor dos inimigos. O ministro italiano afirmou que a capitã Carola Rackete era perigosa para a segurança nacional, assim como o promotor do caso dos Estados Unidos afirmou que o que está em julgamento é que o réu protegeu os dois imigrantes dos agentes da lei. De repente, os imigrantes irregulares pobres são vistos como inimigos e um perigo para a segurança nacional. E, com isso, há um novo tipo de criminoso em cena: os que ajudam esses imigrantes.

Os discursos frequentes de Donald Trump, como candidato e depois como presidente dos Estados Unidos, acentuam que os imigrantes estão "invadindo" os Estados Unidos (assim como antes falavam da "invasão comunista") e que estão colocando em perigo a segurança do país e o bem-estar dos cidadãos. O fato de o muro na fronteira dos Estados Unidos com o México ter se tornado o símbolo da campanha de Trump é significativo, não somente para a cultura norte-americana, mas para o mundo de uma forma geral. Se a imigração se tornou um caso de segurança nacional, muda completamente o paradigma pelo qual essa questão é compreendida e, com isso, os voluntários que defendem os direitos dos imigrantes irregulares podem ser interpretados como criminosos.

O problema que quero discutir aqui não é a questão jurídica ou política, mas a compreensão daqueles que defendem e/ou apoiam a criminalização dos sujeitos e organizações que ajudam os migrantes irregulares em situação de perigo de morte. Por que o que antes era visto como "dever de proteção da vida humana" se tornou um crime, um perigo para a segurança nacional e um mal para as pessoas e a sociedade? As mudanças profundas no sistema jurídico e na política pública pressupõem e, ao mesmo tempo, implicam uma transformação fundamental na compreensão do ser humano. Isto é, nos traz uma pergunta cruel: quais indivíduos são considerados seres humanos e quais, mesmo sendo indivíduos, não-humanos? Em outras palavras, que indivíduos humanos merecem ser tratados e cuidados como humanos em situações de sofrimento e perigo? Qual é o critério do humano?

\section{Identidade, os desejos e medos}

A partir de um projeto iluminista e humanista, a sociedade moderna elaborou tratados ou leis que tentaram preservar a noção de humanidade mesmo em situações desumanas e brutais, como as guerras. Por exemplo: a primeira Convenção de Genebra (1864) estabeleceu que todos os militares feridos ou doentes fossem respeitados e cuidados sem discriminação - 
independentemente de serem nobres ou plebeus, ricos ou pobres - e a terceira (1929) definiu os tratamentos dos prisioneiros de guerra, isto é, os seus inimigos. Mesmo em situações de guerra, não se negava a condição de ser humano dos inimigos.

Contudo, sabemos que as convenções, leis internacionais ou a Declaração Universal dos Direitos Humanos, estabelecidos dentro do projeto de civilização moderna, apresentam uma visão do ideal, e não necessariamente do real observado na sociedade. Todas as sociedades e grupos sociais, na construção de suas identidades, produzem determinados tipos de fantasia de "utopia", os seus sonhos de desejo e dos perigos que lhe ameaçam. Como diz Zygmunt Bauman (1998, p. 52),

Cada sociedade, [...] gera fantasias elaboradas segundo sua própria medida - segundo a medida do tipo de ordem social que se esforça em ser. De um modo geral, tais fantasias tendem a ser imagens espelhadas da sociedade que as gera, enquanto a imagem da ameaça tende a ser um autorretrato da sociedade com um sinal negativo.

Por isso,

a sociedade insegura da sobrevivência de sua ordem desenvolve a mentalidade de uma fortaleza sitiada. Mas os inimigos que lhe sitiaram os muros são os seus próprios 'demônios interiores' - os medos reprimidos e circundantes que Ihe permeiam a vida diária e a 'normalidade', e que, no entanto, a fim de se tornar suportável a realidade diária, devem ser dominados, extraídos do cotidiano vivido e moldados em um corpo estranho, um inimigo tangível com que se possa lutar, e lutar novamente, e lutar até sob a esperança de vencer. (Bauman, 1998, p. 52-53)

Nessa afirmação de Bauman, podemos perceber uma importante relação dialética entre (a) os desejos e a utopia social dos setores da sociedade que defendem a política anti-imigração e (b) a "guerra" deles contra imigrantes-inimigos e os que atuam de forma solidária junto a esses irregulares. A identidade deles, que pressupõe as suas utopias, depende em parte da definição dos seus inimigos/demônios a serem derrotados ou destruídos. A tensão dialética entre o "céu/utopia" e o "inferno/distopia", entre o "anjo" e o "demônio", é parte fundamental desse tipo de construção de identidade pessoal e a social. E, na atual cultura de consumo-globalneoliberal, o que define a diferença entre o "anjo ou demônio", "céu e o inferno", é a capacidade de consumir de um indivíduo, ser rico ou pobre, na luta do mercado capitalista. Em outras palavras, os consumidores falhos, os excluídos do jogo do mercado, são exatamente a encarnação dos seus "demônios interiores". Os consumidores falhos, os pobres, não são vistos como seres humanos em situação de dificuldade econômica, mas sim como manifestações externas de demônios que eles, os integrados na sociedade, 
têm dentro de si. O medo interior e inconsciente de ser como os pobres que aparecem à sua frente.

E o primeiro passo para afastar esse medo de se tornar também um "pecador" é objetificar esse medo na pessoa do pobre-imigrante-irregular. É como se ocorresse um processo de exorcismo em que os demônios interiores fossem expulsos para fora e destruídos na figura dos pobres/imigrantes. E como essas pessoas se consideram puras, trabalhadoras e reconhecidas como "de bem" na sociedade, não haveria para elas a possibilidade de esses medos se tornarem reais. Dessa forma, os pobres seriam vistos como pessoas de essência humana diferente, pecadoras, más e criminosas.

Cada vez mais, em todas as partes do mundo, ser pobre é visto como um "crime", como produto de predisposição, má intenção ou maldição divina ou da natureza (ao contrário da benção divina da prosperidade). Os pobres, especialmente os imigrantes irregulares, ao invés de serem alvo de apoio, cuidado ou assistência, são identificados como a própria encarnação do pecado.

Pecadores e inimigos, é importante ressaltar. Pois, na atual lógica teológica-religiosa neoliberal (Sung, 2018), o pecador não é objeto de misericórdia, compaixão ou perdão - como se poderia pensar em uma concepção religiosa à moda de Jesus de Nazaré, Francisco de Assis ou Buda -, mas é visto como um inimigo a ser eliminado. Isso porque esses imigrantes são acusados de "roubar" os empregos dos que realmente teriam direito e, com isso, reduzem o nível de salário desses e, consequentemente, os mantém mais distantes dos sonhos de consumo.

Os imigrantes irregulares e as pessoas solidárias a eles são categorizadas como inimigos da sociedade, e essa classificação tem uma dimensão religiosa que precisamos aprofundar. Mas, para isso, penso que vale a pena discutirmos rapidamente dois paradigmas distintos de construção de identidade.

No primeiro, que podemos chamar de "paradigma econômicofetichizante", a identidade é vista como uma realidade objetiva que é dada, "em si", como um fetiche. Sem entrar em discussão mais profunda sobre conceitos de fetiche nas ciências da religião, na psicanálise ou na teoria social marxista, podemos assumir aqui a definição do fetiche oferecida pelos dicionários como o objeto a que se atribui poder sobrenatural ou mágico e ao qual se presta culto. Por exemplo, a identidade de um homem branco que se considera superior a uma mulher negra, pelo simples fato de que ela é mulher e negra, depende do culto que ele, e sua comunidade, presta frente ao fetiche "branco-macho". Assim como na cultura de consumo capitalista, a identidade de um rico, ou de classe média, depende do fato de que ele "tem" uma qualidade especial que os pobres não têm: a riqueza. O que diferencia um 
ser humano de um ser não/quase-humano é a sua capacidade de consumir, a sua riqueza. Por isso, nesse paradigma, o que vale é "eu tenho, você não tem" ou "é o que é, ou não é".

Essa identidade não representa algo diferente, ela é o que é em si. Um exemplo no campo da religião cristã nos dá uma ideia mais clara. De acordo com um enfoque teológico, a igreja pode ser vista como um "sacramento", pelo qual se dá a relação entre as pessoas que vivem a fé com Deus; já, de acordo com um outro enfoque, a igreja pode ser pensada como uma "casa", um lugar sagrado, onde as dádivas são produzidas por Deus - ou pessoas sagradas -, reproduzidas e mantidas. Bastaria estar dentro dela e ter a fé. A identidade de um cristão não seria a de viver a fé, a de caminhar nas contradições e desafios da vida com Deus, mas sim ter a "carteira de identidade" de cristão dada pela sua igreja. De forma análoga, a identidade de uma pessoa pobreimigrante estaria dada em si, pelo que têm, para ser marcada como inimigapecadora. A outra pessoa é reduzida à condição de "objeto" visto, manipulado e analisado por um sujeito, o único ser humano na relação. Não haveria nesse ser humano-objeto a sua interioridade e sua história.

No segundo paradigma, que podemos chamar de político, "a identidade é construída por relações interpessoais. O que conta é o inter-relacionamento entre as pessoas. Reconhecimento advém através do papel que alguém desempenha, representando aquilo que está ausente. Os papéis e as regras da performance autenticam a verdade que está sendo reivindicada" (Westhelle, 2017, p. 110). O que é manifestado não é a essência da própria coisa ou da pessoa, mas como ela é vivenciada nas vidas das pessoas que performam seu papel representando aquilo que é da essência.

A forma dominante de impor uma identidade social sobre os imigrantesinimigos é o de impedir a entrada deles na rede de relações intersubjetivas que lhes permitam viver e se relacionar como seres intersubjetivos. E essa inimizade em direção aos imigrantes é parte da identidade dos que lutam contra a solidariedade; a identidade deles é construída por meio do paradigma econômico-fetichizante; tudo gira em termos de objetos ou "verdades absolutas". Por isso, esse tipo de construção de identidade, de si e de outros, precisa de inimigos e da guerra.

\section{O inimigo, que não é humano}

Para entendermos a forma como se dá a criminalização, não só dos imigrantes irregulares, mas também dos "cidadãos" que ousam defender os "inimigos", é preciso ir além da lógica da guerra moderna, que é baseada na relação amigo/aliado vs. inimigo. Na guerra é possível que ocorra um acordo de paz para cessar um conflito demasiadamente custoso para os dois lados. Isso não significa que as condições para negociação sempre estejam presentes 
como possibilidade a priori, porque há situações em que as partes preferem morrer a negociar. São os casos de guerras ou conflitos movidos por círculo de vingança ou causas divinas. E esses conflitos só chegam à conclusão quando o inimigo está eliminado completamente ou quando se elimina a motivação da vingança ou da guerra religiosa.

Por exemplo, nos casos das guerras religiosas pós Reforma Protestante, chegou-se a uma solução de paz negociada por meio da separação entre o Estado e a Igreja. Isto é, ao reconhecer que as guerras em nome de Deus estavam levando à destruição dos dois lados em disputa, encontrou-se um caminho para uma paz negociada por meio da separação entre eles: de um lado o Estado - o campo da guerra e da política - e do outro a Igreja. É o que se chamou de processo de secularização. Com o fim do caráter religioso-divino da guerra, a negociação se tornou possível. Nesse sentido, a secularização e a guerra moderna são filhos da modernidade.

No fundo, o que reconhecemos, mesmo em um âmbito de guerra, é a humanidade comum de todos os seres envolvidos e a importância da manutenção da vida. Porém, o que estamos vendo no âmbito da mobilidade humana contemporânea é uma situação diferente em que se nega a humanidade do inimigo-imigrante, os seus direitos de serem ajudados em situações de perigo de morte.

Nessa perspectiva, estamos além ou aquém da lógica amigo vs. inimigo do âmbito da civilização moderna secularizada. De uma certa forma, podemos dizer que estamos vivendo uma época de "guerra santa" contra inimigosimigrantes, uma guerra em que a lógica não é integralmente racional. Se for verdade que estamos fora do campo de "guerra moderna" e estamos em um tipo de "guerra santa", talvez valha a pena recuperarmos alguns conceitos do campo religioso-teológico antigo para entendermos melhor o que está acontecendo hoje. Em particular, algumas discussões sobre o "sagrado" na dinâmica social no mundo contemporâneo.

Com a secularização e a racionalidade moderna, especialmente no campo das ciências sociais modernas, há muitas polêmicas, em favor ou contra o sagrado/religião, que não nos ajudam muito na compreensão do nosso problema (e posso dizer com trinta anos de experiência no campo das ciências da religião e da teologia, que provavelmente vai levar muito tempo para um acordo na comunidade acadêmica). Porém, sem entrar em discussões inúteis para o nosso tema do "inimigo-imigrante", penso que vale a pena retomarmos a ambiguidade interna da noção de sagrado no mundo antigo.

Giorgio Agamben (2002, p. 9) nos lembra que os gregos usavam dois termos, semântica e morfologicamente distintos, para falar de vida: "zoé, que 
exprimia o simples fato de viver, comum a todos os seres vivos (animais, homens ou deuses); e bíos, que indicava a forma ou maneira de viver própria de um indivíduo ou de um grupo". A passagem do zoé para o bíos implica pertencer ao campo da pólis, ao campo do humano e da ligação entre o sagrado e o profano. Na cosmovisão religiosa, a manifestação do sagrado, - que é o fundamento da consagração de pessoas sagradas, sacerdotes com poder de performar ritos sagrados e, com isso, consagrar coisas, objetos, lugares, em tempos sagrados - é o fundamento do cosmos e da vida profana. E, como nos lembra Agamben (2002, p. 87),

A estrutura da sacratio resulta, tanto nas fontes como segundo o parecer unânime dos estudiosos, da conjunção de dois aspectos: a impunidade da matança e a exclusão do sacrifício. [...] Tem sido observado que enquanto a consecratio faz normalmente passar um objeto do ius humanum ao divino, do profano ao sacro, no caso do homo sacer uma pessoa é simplesmente posta para fora da jurisdição humana sem ultrapassar para divina.

O homo sacer é aquele que, tendo cometido um crime hediondo, não pode ser sacrificado segundo os ritos de punição, isto é, segundo ritos de punição que fazem parte da lógica interna do sistema vigente e são vistos como produtores de algo positivo. Em outras palavras, há punições que são positivas para as pessoas e o sistema, e essas são controladas de acordo com ritos sagrados, isto é, sacrifícios. No caso de homo sacer, ele está completamente fora do âmbito do sagrado e o seu crime - ou a sua condição social - é tão hediondo que ele se tornou matável, mas ao mesmo tempo é insacrificável, isto é, a sua morte não é regulada pelas leis rituais (na sociedade antiga, não havia separação entre as leis religiosas-rituais e as leis civis) e dela não pode surgir nada de positivo. Nem os deuses podem tirar algo de bom da vida e da morte dele.

Para entendermos um pouco melhor essa noção de homo sacer, que para o mundo moderno ocidental é quase incompreensível, penso que vale a pena trazer aqui um diálogo que eu tive com um aluno indiano dalit em um curso internacional de mestrado e doutorado em teologia, em uma universidade em Seul, Coréia do Sul. O grupo era formado por estudantes do "Terceiro Mundo" e, na apresentação da turma, esse indiano cristão protestante se apresentou como um dalit, para em seguida perguntar: "O senhor sabe o que significa ser dalit?". Eu lhe pedi para falar um pouco sobre isso. Ele respondeu: "Na Índia, há ritos religiosos hindus específicos para todas as situações. Quando, por exemplo, algum animal doméstico morre, há ritos específicos para a celebração. Mas, no caso da morte de um dalit, é proibido fazer esses rituais. Nós somos vistos como inferiores aos animais".

Os dalit, e de uma certa forma também os imigrantes que não merecem ajuda mesmo em situações de morte, são essas pessoas que são matáveis e, ao 
mesmo tempo, insacrificáveis; isto é, não servem para nada de bom e sagrado. Das mortes deles não pode surgir nada de bom, de produtivo ao sistema como, por exemplo, diminuir os pecados do povo ou oferecer aos deuses como expiação dos seus pecados. Isso não quer dizer que a classificação dos dalits não tenha uma função social importante: a existência social dos dalit serve para estabelecer as fronteiras entre os "humanos-criminosos", que ainda são humanos apesar dos seus crimes, e os não-humanos.

Temos, assim, de um lado, os sacerdotes, os seres humanos excluídos do mundo profano porque são consagrados e performam os sacrifícios; de outro, os homini sacri, os seres tão excluídos da vida humana que são matados fora da lógica e do ritual sacrificial; podem ser matados sem grandes problemas, assim como as mulheres dalit estupradas sem criminalização. E, no meio, os seres humanos "normais", incluindo os criminosos que são humanos.

Em resumo, o que nos interessa nessa discussão é "a impunidade da matança e a exclusão do sacrifício". Na lógica e estrutura do sagrado, há dois tipos de pessoas "sagradas", separadas, excluídas: (a) o sacerdote que pode e deve matar, sacrificar, para oferecer aos deuses - isto é, o fundamento último da ordem social -; e (b) homo sacer, uma pessoa que é simplesmente posta para fora da jurisdição humana, sem nunca chegar ao divino, tão excluída da ordem sagrada que pode ser matada impunemente. É importante destacar que a ordem social sacrificial trata as mortes dessas pessoas consideradas insacrificáveis como não necessárias para a manutenção da ordem, isto é, não reconhece suas mortes como sacrifícios necessários, portanto úteis. Mas, na verdade, elas são necessárias. Isso porque, nos momentos em que a ordem sacrificial não é capaz de realizar as suas promessas em troca dos sacrifícios oferecidos por parte das pessoas "normais" da sociedade, a ordem social entra em crise e precisa justificar a razão das frustrações das promessas não realizadas. Nessas situações, a sociedade sacrifica os seres humanos considerados não-sacrificáveis e coloca sobre seus ombros a culpa e frustrações da própria sociedade.

Dessa forma, podemos diferenciar dois tipos de sacrifícios: a) sacrifícios oferecidos pelos "incluídos" na sociedade, por meio dos sacerdotes, e que são vistos como sacrifícios úteis, produtivos; b) sacrifícios dos "não-humanos" (pobres-imigrantes), reais e "úteis" para a manutenção da ordem, mas que são interpretados pela cultura dominante como não-sacrifício, apenas como mortes não importantes.

Voltando à nossa discussão sobre os imigrantes-inimigos, perdemos - ou estamos perdendo - o avanço civilizatório que reconhece o caráter humano do nosso inimigo, isto é, reconhece a dignidade humana de todas as pessoas mesmo que esse outro esteja ocupando um lugar social de inimigo. É claro 
que o ensinamento de Jesus sobre amar aos inimigos não é muito factível na vida social, mas o reconhecimento social da dignidade humana de todas as pessoas era, e é ainda, factível. Porém, estamos vivendo o crescimento de uma cultura em que o inimigo não é humano. Os imigrantes irregulares, mais do que inimigos que devem ser tratados de acordo com as convenções de guerra, estão sendo vistos como criminosos que corrompem a "pureza" da sociedade autóctone, como um tipo de epidemia social. E frente aos contágios que corrompem ou podem corromper a ordem social desejada, é preciso impedir que eles cheguem ao seu destino indevido, separá-los, excluí-los e eliminá-los. É como o homo sacer do nosso tempo.

A criminalização da ajuda aos imigrantes irregulares, e dos que lutam contra as leis e programas securitários de "proteção" da ordem social, revela o imaginário coletivo instaurado acerca dos imigrantes. Essa identidade não é vista dentro de um paradigma de relações intersubjetivas, mas na relação eu-objeto, paradigma econômico-fetichista. Os imigrantes não são vistos apenas como pessoas que criam um problema social, um problema de seres humanos que não têm lugar e função dentro da ordem desejada pelos anti-imigração, mas, mais do que isso, são tidos como pessoas de essência má.

\section{Os deuses modernos e os sacrifícios}

Como vimos acima, o medo dos inimigos também tem relação com os desejos e utopias do sistema social dominante. Por isso, o conceito de homo sacer e o de "guerra santa" são necessários ou úteis, mas não suficientes. Precisamos de um conceito ou um quadro teórico mais amplo capaz de articular esses dois lados da relação. Continuando a discussão do sagrado e do sacrifício, e da diferença entre o sacrificável e o insacrificável, penso que há uma afirmação de $\mathrm{M}$. Weber que vale a pena aprofundar. Ao discutir a possibilidade ou não de decidir "cientificamente" o valor da cultura francesa face à cultura alemã, Weber (1984) diz que, assim como no passado, há também no nosso tempo uma guerra entre deuses. Como diz M. Löwy (2000, p. 9), essa expressão "guerra dos deuses" é uma referência ao politeísmo dos valores e ao conflito insolúvel das crenças básicas, os chamados "deuses", na sociedade moderna: "falando sem metáforas, as possíveis atitudes básicas com relação à vida são irreconciliáveis e, portanto, a luta entre elas nunca poderá ser levada a uma conclusão final. É necessário, portanto, fazer uma escolha definitiva".

No fundo, Weber já anuncia a discussão pós-moderna sobre a impossibilidade (ou possibilidade, segundo os críticos do pensamento pós-moderno radical) de decidir se a cultura francesa, com suas produções artísticas e culinárias, é superior à cultura alemã ou, por exemplo, à japonesa. Mas é preciso diferenciar os tipos de aporias em jogo no reconhecimento 
dos limites da razão. Um diálogo sobre a superioridade ou não da culinária francesa, com suas sofisticações e etiqueta à mesa, e da culinária coreana, que mistura muitos sabores e pratos, com etiqueta à mesa que parece incivilizada aos olhos europeus, é impossível. Eu tive essa experiência com uma amiga francesa teóloga e pró-pluralismo cultural. Na prática, esse diálogo resultou impossível. A saída foi: uma noite comeremos à regra francesa, na outra, à coreana. O problema é que os conflitos sociais e os valores fundamentais de um sistema social não podem ser resolvidos como se fossem uma discussão estética e sem decisão final.

Por isso, cada sistema social - e estamos vivendo no interior da divisão social do trabalho globalizado - absolutiza os critérios e valores fundamentais. Princípios esses que são vistos como superiores aos desejos e direitos dos indivíduos. Em outras palavras, o seu "deus". Em situações de conflitos ou guerras em nome de diferentes valores e princípios fundamentais, há, de fato, uma infindável "guerra dos deuses", que acontece a partir de conflitos imanentes, motivados por questões transcendentais.

Essa análise nos leva a entender a importância da discussão sobre o "deus" e os sacrifícios exigidos em seu nome. É a exigência de sacrifícios de vidas humanas que mostra o poder e a importância desse deus; e a função última do deus, com sua religião, não é garantir a salvação pós-morte, mas sim a ordem social dominante.

O que nos interessa aqui não é a questão da secularização ou do desencantamento do mundo na modernidade, ou o que significa "deuses" ou "divino/absoluto" no mundo moderno, mas sim a afirmação de Max Weber (1984, p. 42, grifo meu) que diz:

Tudo se passa, portanto, exatamente como se passava no mundo antigo, que se encontrava sob o encanto dos deuses e demônios, mas assume sentido diverso. Os gregos ofereciam sacrifícios (...) aos deuses das cidades; nós continuamos a proceder de maneira semelhante, embora nosso comportamento haja rompido o encanto e se haja despojado do mito que ainda vive em nós.

Os "deuses" modernos não são mais como são os deuses da antiguidade, marcados pelo encantamento e ritos sacrificiais, mas continuam sendo deuses que, sob a forma de poderes impessoais, exigem sacrifícios.

"Deus" - como fundamento último da ordem social -, guerras dos deuses e sacrifícios necessários são questões subjacentes à discussão do tema deste artigo. Os argumentos dos voluntários, que preferem correr o risco de prisão em favor dos imigrantes, fazem sentido no interior de uma cosmovisão em que todas as pessoas humanas, independentemente de sua cidadania, etnia ou pobreza, têm dignidade fundamental e, por isso, têm direitos humanos. E entre esses direitos, os direitos de serem ajudados em 
situações de perigo de morte e de tentarem uma vida melhor em outro país. Por outro lado, os defensores da política de segurança nacional em relação aos imigrantes irregulares são defensores dos seus direitos de terem segurança e tranquilidade em suas cidades e país, de realizarem os seus desejos de consumo, que percebem como sendo ameaçados com a vinda desses imigrantes, além de terem o desejo de uma convivência racial e/ou étnica mais homogênea e "pura". Os dois lados possuem os seus princípios fundamentais absolutos, isto é, princípios que valem em si, sem necessidade de pressuposto de uma argumentação racional anterior. Se precisassem dessa argumentação anterior não seriam princípios fundamentais.

Nas sociedades pré-modernas o nome desse fundamento último era Deus ou os seus deuses. Com a modernidade, Deus deixou de ser o fundamento último da verdade e dos valores, mas isso não significou que a ordem social não necessita de um fundamento último. O que aconteceu é que a "racionalidade religiosa" foi substituída pela "Razão" moderna e o mito do progresso. Com os avanços da discussão filosófica e científica, especialmente a discussão sobre a linguagem e o pluralismo cultural, o edifício da cultura moderna colapsou e a "racionalidade pós-moderna" assumiu o lugar. Porém, essa crítica pós-moderna não é e não será capaz de oferecer os critérios últimos para as decisões necessárias diante das "guerras dos deuses": qual deus, ou princípios últimos, a escolher? E aqui a decisão não é entre a cultura francesa ou alemã, ou entre a norte-americana e a chinesa; mas sim entre "os imigrantes-irregulares-pobres têm o direito de serem ajudados" ou "os imigrantes são os inimigos a serem expulsos"?

A impossibilidade de uma tomada de posição científica a respeito é uma resposta aceitável no âmbito do universo acadêmico, mas não é suficiente na vida real, especialmente em discussões políticas tão calorosas como essas.

No fundo, estamos diante da pergunta sobre "o que faz um indivíduo ter o direito de viver dignamente apesar de ser não-consumidor e não-cidadão"? Uns poderiam responder: a sua dignidade, os direitos humanos; e, outros, nada. Para estes, não há direitos humanos. Tudo isso seria uma invenção da modernidade de origem cristã. Como diz um dos principais nomes do neoliberalismo, Ludwig von Mises (2008, p. 80), em um texto de 1956, fundamental para a cultura neoliberal, "a pior de todas essas ilusões (delusion) [como direitos humanos] é a ideia de que a 'natureza' conferiu a cada indivíduo certos direitos [...] só pelo fato de terem nascido". Não haveria direitos humanos, só direitos resultados do contrato no livre mercado.

Estamos diante de dois sistemas de valores distintos e conflitantes. E aqui é importante ressaltar que estamos lidando não somente com sistemas de valores diferentes, - que poderiam ter suas diferenças, mas também 
com semelhanças e convergências - mas sim, com sistemas "distintos", isto é, conflitantes e incompatíveis. Para pessoas solidárias com os imigrantes irregulares, há sim direitos humanos que são fundados na noção de dignidade humana, anteriores aos direitos legais e aos do mercado. Para outras, entretanto, só há direito de serem tratadas como iguais frente à lei do mercado e, por isso, os direitos de propriedade e do consumidor. Isto é, o fundamento último do direito está no mercado "livre". Para os defensores dos direitos sociais - uma dimensão dos direitos humanos -, a necessidade urgente de defender a vida dos pobres e o meio-ambiente justifica sacrificar pelo menos uma parte do desejo de aumentar o consumo e a produção de riqueza no mundo. Por outro lado, os fascinados por aumento de riqueza e consumo justificam os sacrifícios dos pobres e dos "inúteis".

Sem uma lógica do sacrifício, nenhum sistema social - seja capitalista ou socialista, ou uma alternativa a surgir - pode ser operacional, pois frente aos desejos insaciáveis dos seres humanos sempre haverá escassez. Entretanto, há, pelo menos, dois tipos de sacrifícios nessa discussão: um que, em nome do direito à vida de todas as vidas, justifica o sacrifício dos desejos de bens de consumo, propriedade e/ou poder; e um outro que, em nome dos desejos de consumo e finalidades político-econômicas, sacrifica vidas humanas.

Em resumo, podemos aceitar que não é possível cientificamente definir se a cultura francesa é melhor ou pior do que a alemã, mas podemos - e devemos - ter critérios racionais e éticos para escolher entre um (a) "deus" que justifica os sacrifícios de vidas humanas em nome do aumento da riqueza ao mesmo tempo que nega a condição humana dos pobres e imigrantes irregulares; e (b) um outro "deus" que sacrifica desejos de consumo conspícuo em nome da vida dos pobres e vulneráveis. Sem isso, o que nós entendemos como civilização humana está em perigo.

\section{Idolatria e a vida humana}

Se estamos diante do desafio de distinguir entre esses dois "deuses", ou dois princípios e valores absolutos que fundamentam a ordem social que sacrifica ou não a vida humana, estamos diante de um desafio "teológico" fundamental. Antes de o leitor se sentir "estranho" ou mal diante desse desafio que pensava não mais existir após o desencantamento do mundo moderno, quero deixar bem claro que não estamos falando da teologia como "um logos sobre Deus", no sentido grego-medieval tradicional. O que está em jogo aqui é o discernimento dos deuses - ou princípios absolutos como "Livre Mercado" ou do "Estado Comunista" da antiga União Soviética - que justificam a criminalização ou não dos imigrantes irregulares e dos voluntários e solidários a esses. 
Como a racionalidade moderna e a pós-moderna, no estado que temos, não têm condição para definir sobre os princípios absolutos, e suas epistemologias não parecem suficientes para decidir essas questões tão fundamentais ao nosso mundo, quero retomar um conceito usado especialmente por alguns intelectuais do século XX da tradição judaica: a idolatria.

O conceito de "idolatria", da tradição bíblica, não se refere à discussão sobre a existência ou não de Deus, mas sim ao discernimento entre diversas imagens de Deus que fundamentam uma ordem social e os seus sistemas de valores.

Na década de 1950, Erich Fromm (2002, p. 56-57) criticou

o culto do Estado, misturado com a idolatria da raça ou nação. O fascismo, o nazismo e o stalinismo são as manifestações mais drásticas dessa mistura de estado e adoração de clã, ambos princípios incorporados na figura de um 'Fuhrer'. [...] O nacionalismo é a nossa forma de incesto, é a nossa idolatria, é a nossa insanidade. 'Patriotismo' é o seu culto.

Esse tema de idolatria e imigração, interpretado a partir da cultura neoliberal, que é recente, não pode ser atribuído ao Fromm, mas quero chamar atenção em relação ao uso do conceito de idolatria nessa discussão sobre o culto da raça ou nação. Além disso, é claro também que o tema do neoliberalismo, e o seu princípio absoluto do "livre mercado" e o possível uso do conceito de idolatria, ainda não estavam presentes nessa época.

$\mathrm{Na}$ década de 1960, Fromm (2005, p. 72-73), propondo uma interpretação radical do Antigo Testamento, disse:

Um ídolo representa o objeto central da paixão humana: o desejo de retornar ao solo materno, o desejo de possessão, poder, fama e etc... A paixão representada pelo ídolo é, ao mesmo tempo, o valor supremo dentro do sistema de valores humano. [...] Talvez seja suficiente dizer que a história da humanidade até o presente é basicamente a história do culto a ídolos, desde os ídolos primitivos de argila e madeira até os modernos ídolos do estado, produção e consumo - santificados pela bênção de um Deus idolatrado.

Para ele, não é possível ao ser humano elaborar uma teologia no sentido positivo de um discurso correto sobre Deus, porque Deus está além da razão humana, porém a "ido-logia" - a ciência dos ídolos - é possível e necessária.

Nesse mesmo sentido, Max Horkheimer (1976, p. 103) também nos diz: "Não podemos comprovar a existência de Deus. O conhecimento consciente do desamparo, da nossa finitude, não se pode considerar como prova da existência de Deus, senão que tão somente pode produzir a esperança de que exista um absoluto positivo". Isto é, não podemos definir ou determinar o que é o último. Pois como ele diz, "Qualquer ser limitado - e a humanidade é limitada - que se considera como o último, o mais elevado e o único, se 
converte em um ídolo faminto de sacrifícios sanguinários, e que tem, ademais, a capacidade demoníaca de mudar a identidade e de admitir nas coisas um sentido distinto" (Horkheimer, 1976, p. 68).

Os ídolos são coisas que podemos construir, mas eles depois de construídos não são mais conhecidos enquanto tais. Eles não são mais Baal ou Moloch, não pertencem mais a uma determinada religião estranha ou ultrapassada, mas eles trazem nomes respeitáveis como "honra", "soberania do Estado" ou "Livre Mercado". "Acobertados de absoluta racionalidade, como técnica; objetos do nosso esforço enraizado na natureza humana, como consumo; afinal o próprio Deus torna-se ídolo, em nome do qual são abençoados todos os ídolos" (Fromm, 1972, p. 834).

A proposta de nomenclatura de "idologia", de Fromm, não foi para frente. Ao comentar o uso que Marx fez de Moloch, a quem muitas populações deveriam ser sacrificadas, como uma metáfora do capitalismo, Fromm disse que "Marx é o representante mais consequente da 'teologia negativa'. Ele não fala de Deus, mas dos ídolos e do alienado, isto é, do homem escravo dos ídolos" (Fromm, 1972, p. 828). O que me interessa aqui não é se a nomenclatura "idologia" é apropriada ou se devemos procurar uma outra, como "teologia negativa", "teologia profana" - proposta por Franz Hinkelammert (Fernández Nadal, Silnik, 2012) - ou como propõe Edgar Morin (2000, p. 53-54), noologia - estudo do âmbito do imaginário, dos mitos, das ideias ou dos deuses pelos quais as pessoas e grupos sociais são possuídos e pelos quais são capazes de morrer ou matar -, mas sim a importância dos conceitos de ídolo e idolatria.

Para Hugo Assmann (Assmann, Hinkelammert, 1989), um dos teólogos da libertação latino-americanos que mais estudou a questão da relação entre teologia e economia usando o conceito de "idolatria do mercado" - ademais foi leitor de Fromm e Horkheimer, e estudou com Adorno em Frankfurt -, "ídolos são os deuses da opressão. Biblicamente, o conceito de ídolo e idolatria está diretamente vinculado à manipulação de símbolos religiosos para criar sujeições, legitimar opressões e apoiar poderes dominadores na organização do convívio humano" (Assmann, Hinkelammert, 1989, p. 11). Isto é, ele assume a perspectiva da tradição bíblica que faz do conflito libertação-opressão e vida-morte o critério fundamental entre Deus-da-Vida e deus-ídolo. Ele não está preocupado com as discussões "escolásticas" entre razão e fé, imagem e essência de Deus, ou a existência ou não de Deus. A questão central para ele é: "se falamos em idolatria e 'perversas teologias', presentes na economia é porque nos preocupa o sacrifício de vidas humanas legitimado por concepções idolátricas dos processos econômicos" (Assmann, Hinkelammert, 1989, p. 12). 
E como vimos no percurso da argumentação, a questão do ídolo ou deus como fundamento último da ordem social e da vida das pessoas dentro da qual está em jogo a vida ou morte dos imigrantes-pobres e dos voluntários solidários - está profunda e dialeticamente articulada com a questão da subjetividade humana. O problema não é fruto de uma maldade moral de algumas pessoas ou grupos, nem é resultado de uma estrutura social essencialmente perversa, mas sim de uma lógica da relação entre os idólatras e o ídolo.

Como diz Assmann (1989, p. 410),

A idolatria é um ato de reciprocidade entre o idólatra e o ídolo. Poderão objetar que isso não é possível porque o ídolo é uma coisa, um objeto; portanto, carente de subjetividade. Se fosse assim, o ídolo não teria nenhum poder real, não poderia exercer nenhum poder num ato de reciprocidade com o idólatra. Mas, como vimos, no capitalismo se dá precisamente esta inversão: as coisas viram sujeitos e os sujeitos, as coisas. A 'teoria do fetichismo', no fundo, é uma explicação do estranho poder das coisas sobre as pessoas. [...] $\mathrm{O}$ fetiche se tornou historicamente verdadeiro, porque a realidade fetichizada funciona segundo as leis do fetiche.

Para entendermos um pouco mais a importância ou utilidade da noção de idolatria do mercado na compreensão dos problemas em torno dos imigrantes irregulares como "criminosos-pecadores", vale a pena trazer aqui como um exemplo o estudo feito pela Rachel Simon-Kumar (2014) sobre o papel do neoliberalismo nas mudanças do perfil dos imigrantes desejados na Nova Zelândia. Na década de 90, o perfil do imigrante desejável era marcado pela raça - pela política de branqueamento do país -, mas, no século XXI, mudou para o perfil de alguém que compartilha semelhanças na cultura consumista global, independentemente da raça. Isso significa que, na cultura neoliberal global, o critério último para a exclusão da condição de "ser humano desejável" é o Livre Mercado.

\section{Conclusão}

$\mathrm{Na}$ atual cultura neoliberal global, o que faz o indivíduo humano ser reconhecido como ser humano é a sua capacidade de consumir e enriquecer no mercado; por isso espalha-se o medo de ser visto como um consumidor-falho, como um pecador ou, pior do que isso, como um "matável não-sacrificável". A noção de ídolo-idolatria nos ajuda a entender a dialética entre o obsessivo desejo de consumo e o medo e a guerra contra os imigrantes e pobres; e de como pessoas moralmente "boas" podem ser tão insensíveis diante dos sofrimentos dos imigrantes-pobres e pobres não-imigrantes, mas inimigos da sociedade. 
Por outro lado, a prática dos voluntários em favor dos imigrantes, assim como em favor dos pobres e excluídos da sociedade, nos mostra que há um outro tipo de "deus" presente nessas lutas marcadas por compaixão e solidariedade. Não é fácil definir racionalmente o "ser" desse movimento, o espírito que leva as pessoas e grupos a lutarem pela dignidade de todos e todas. O importante é mostrar, revelar, a mentira do ídolo e da idolatria que domina hoje e lutar pela vida.

\section{Referências bibliográficas}

AGAMBEN, Giorgio. Homo sacer: o poder soberano e a vida nua, I. Belo Horizonte: Ed. UFMG, 2002.

ASSMANN, Hugo; HINKELAMMERT, Franz. A idolatria do mercado: ensaio sobre economia e teologia. Petrópolis: Vozes, 1989.

BAUMAN, Zygmunt. Consuming Life. Cambridge (UK)-Malden (USA): Polity, 2007. BAUMAN, Zygmunt. O mal-estar da pós-modernidade. Rio de Janeiro: Jorge Zahar Ed., 1998.

FERNÁNDEZ NADAL, Estela; SILNIK, Gustavo David. Teología profana y pensamiento crítico: Conversaciones con Franz Hinkelammert. Buenos Aires: CICCUS/CLACSO, 2012.

FROMM, Erich. Algumas reflexões pós-marxistas e pós-freudianas sobre a religião e a religiosidade. Concilium, Petrópolis: Vozes, n. 76, 1972/6, p. 827-834.

FROMM, Erich. O Antigo Testamento: uma interpretação radical e sua tradição. São Paulo: Novo Século, 2005.

FROMM, Erich. The Sane Society. London: Routledge Classics, 2002.

GUIA , Maria João; PEDROSO , João. A insustentável resposta da "crimigração" face à irregularidade dos migrantes: uma perspetiva da união europeia. REMHU, Revista Interdisciplinar da Mobilidade Humana, Brasília, v. 23, n. 45, p. 129-144, jul./dez. 2015.

HORKHEIMER, Max. La añoranza de lo completamente otro. In: MARCUSE, Herbert; POPPER, Karl; HORKHEIMER, Max. A la búsqueda del sentido. Salamanca: Sígueme, 1976, p. 67-124.

LÖWY, Michael. A guerra dos deuses: Religião e política na América Latina. Petrópolis: Vozes, 2000.

MISES, Ludwig von. The Anti-Capitalist Mentality. Auburn: Ludwig von Mises Institute, 2008.

MORIN, Edgar. A cabeça bem-feita: repensar a reforma, reformar o pensamento. Rio de Janeiro: Bertrand Brasil, 2000.

O GLOBO. Capitã de barco que resgata imigrantes do mar é presa ao atracar na Itália. 28/06/2019. Disponível em: <https://oglobo.globo.com/mundo/capita-debarco-que-resgata-imigrantes-do-mar-presa-ao-atracar-na-italia-23773497> . Acessado em: 20/08/2019. 
PENCHASZADEH, Ana Paula; SFERCO, Senda Inés. Solidaridad y Fraternidad. Una nueva clave ético-política para las migraciones. REMHU, Revista Interdisciplinar da Mobilidade Humana, Brasília, v. 27, n. 55, p. 149-164, Apr. 2019.

SIMON-KUMAR, Rachel. Neoliberalism and the New Race Politics of Migration Policy: Changing Profiles of the Desirable Migrant in New Zealand. Journal of Ethnic and Migration Studies, v. 41, n. 7, p. 1-20, December 2014.

SUNG, Jung Mo. A idolatria do dinheiro e os direitos humanos: uma crítica teológica do novo mito do capitalismo. São Paulo: Paulus, 2018.

WEBER, Max. Ciência e política: duas vocações. São Paulo: Cultrix, 1984.

WESTHELLE, Vítor. O evento igreja: chamado e desafio a uma igreja protestante. São Leopoldo: Sinodal-EST, 2017. 